\title{
"Transpadanos et Ambranos” w działaniach politycznych G. Juliusza Cezara w latach 60. I wieku p.n.e.
}

\begin{abstract}
Abstrakt: W latach 60. I wieku p.n.e. ważnym czynnikiem w polityce rzymskiej była sprawa przyznania pełnego obywatelstwa ludności prowincji Galii Przedalpejskiej zamieszkującej tereny za rzeką Pad. W swojej działalności politycznej do tego postulatu odwoływał się G. Juliusz Cezar, który już w 67 roku p.n.e. próbował wykorzystać niezadowolenie tzw. Transpadanów ze swojego statusu prawnego. W kolejnych latach Cezar sięgał po wsparcie ze strony mieszkańców Galii Przedalpejskiej, nie tylko podsycając ich nastroje w 65 roku p.n.e., lecz także prowokując do wystąpień tajemniczych "Ambranos". Efektem tych działań była budowa relacji klienckich, które przyniosły mu duże korzyści w walce o władzę w latach 50. i 40. I wieku p.n.e.
\end{abstract}

Słowa kluczowe: „causa Transpadanorum”, G. Juliusz Cezar, północna Italia, „Gallia Cisalpina”, „Transpadani”

W drugiej połowie 59 roku $^{1}$ trybun ludowy i zwolennik Cezara, P. Watyniusz, przeprowadził na zgromadzeniu lex Vatinia de provincia Caesaris, która oddawała w zarząd Cezarowi jako namiestnikowi Galię Przedalpejską, Ilirię oraz Galię Narbońską (tę ostatnią otrzymał od senatu, ponieważ zmarł jej dotychczasowy namiestnik Kw. Cecyliusz Metellus Celer) ${ }^{2}$. W trakcie swego długiego namiestnictwa udało mu się podporządkować dla Rzymu nie tylko ogromne obszary dzisiejszej

\footnotetext{
${ }^{1}$ Wszystkie daty wymienione w tekście artykułu odnoszą się do czasów przed Chrystusem.

${ }^{2}$ Lex Vatinia: Cic., Att. 8, 3; Vat. 15; Sest. 64; Prov. cons. 15; 17; Liv., per. 103; Vell. II, 44; Plut., Caes. 14; Pomp. 48; Crass. 14; Cat. Min. 33; Suet., Iul. 22; App., BCXIV, 13, 48; Cass. Dio XXXVIII, 8; Oros. VI, 7, 1; G. Luraschi, Foedus Ius Latii Civitas - Aspetti costituzionali della romanizzazione in Transpadana, Padova 1979, s. 379-394; K. Bringmann, Historia republiki rzymskiej, przeł. A. Gierlińska, Poznań 2010, s. 236-263. Przekazanie Galii Narbońskiej Cezarowi: T.C. Brennan, The Praetorship in the Roman Republic, vol. 2, Oxford 2000, s. 579.
} 
Francji, należące do licznych plemion celtyckich, oraz odbyć wyprawę do Brytanii, lecz przede wszystkim zostać najbardziej wpływowym politykiem w republice i wygrać rywalizację o władzę z Gn. Pompejuszem Wielkim³ ${ }^{3}$. Możliwości militarne i logistyczne, jakie dawały mu wszystkie jego prowincje, $w$ tym największa $z$ nich Gallia Cisalpina, odegrały w jego drodze do jedynowładztwa niebagatelną rolę ${ }^{4}$. Pobyt Cezara w Galii Przedalpejskiej w latach 50. nie był jednak jego pierwszym kontaktem z tymi terenami, a początków jego związków z tą prowincją należy doszukiwać się znacznie wcześniej, a mianowicie u progu lat 60. I wieku.

Cezar swą drogę do wielkiej kariery zaczynał jako mało znaczący uczestnik politycznych gier, głównie ze względu na młody wiek i niezbyt imponującą pozycję. Nie wynikało to z braku zdolności. System polityczny w Rzymie wprowadzał ograniczenia wynikające $\mathrm{z}$ wieku oraz przerwy w pełnieniu urzędów w cursus honorum, czego przykładem były ustawy Sulli leges Corneliae de annalis i de magistribus ${ }^{5}$. Młody Cezar doskonale jednak wyczuwał sytuację polityczną ówczesnego Rzymu w danym momencie. Był związany, dzięki koneksjom rodzinnym, z polityczną opcją popularów. Jego ciotką była żona wielkiego wodza G. Mariusza, a żoną — Kornelia, córka drugiego wybitnego populara, L. Korneliusza Cynny. Właśnie na początku lat 60. dał wyraz swym politycznym sympatiom i rodzinnym koneksjom, prezentując na pogrzebach ciotki i żony wizerunki G. Mariusza, co wzbudziło liczne kontrowersje.

Sytuacja polityczna w Rzymie na przełomie lat 70. i 60. I wieku była złożona. W związku z podważeniem pozycji i autorytetu następców Sulli wpływ na władzę mieli znów popularzy, którzy porozumieli się z dawnymi dowódcami Sulli M. Licyniuszem Krassusem i przede wszystkim Gn. Pompejuszem Wielkim ${ }^{6}$.

${ }^{3}$ Caes., Bell. Civ. 3, 87; Liv., per. 110; Luc., Phars. IV, 462; E.G. Hardy, Some Problems in Roman History. Ten Essays bearing on the administrative and legislative work of Julius Caesar, Oxford 1924, s. 51-54, 132; U. Ewins, Enfranchisement of Cisalpine Gaul, „Papers of the British School of Rome” 1955, 23, s. 82-83; H. Galsterer, Aspetti della romanizzazione nella Cisalpina, „Antichità Altoadriatiche" 1991, 37: Preistoria e protostoria dell'Alto Adriatico, s. 171-172; E. Buchi, Roma e la Venetia orientale dalla guerra sociale alla prima età augustea, w: Studi e ricerche sulla Gallia Cisalpina. Vigilia di romanizzazione. Altino e il Veneto orientale tra II e I sec. a.c. Atti del Convegno, Venezia, S. Sebastiano, 2-3 dicembre 1997, Roma 1999, s. 310-311.

${ }^{4}$ M. Piegdoń, Caesar et Transpadani: ludność Galii Cisalpejskiej w polityce Gajusza Juliusza Cezara, „Nowy Filomata” 2004, 8 (4), s. 259-270; Idem, Galia Przedalpejska. Studia nad rzymska obecnościa w pótnocnej Italii w III-I w. p.n.e., Kraków 2009, s. 113-119, 171-172.

${ }^{5}$ Ustawy Sulli: Cic., Phil. 5, 48; Leg. Agr. 2, 3; Off. 2, 17; Plut., Sull. 33; App., BC XIII, 101; M. Cary, H.H. Scullard, Dzieje Rzymu, t. 1, przeł. J. Schwakopf, Warszawa 1992, s. 357, 403, 456-463; R. Seager, Sulla, w: The Cambridge Ancient History, vol. 9, eds. J.A. Crook, A. Lintott, E. Rawson, Cambridge 1994, s. 203; H. Kowalski, Rola polityczna kapłanów w Rzymie w okresie schyłku Republiki, w: W 2500-lecie powstania Republiki Rzymskiej, red. A. Kunisz, Katowice 1995, s. 33. Sulla zorganizował na terenie Italii prowincję — Galię Cisalpińską, zob. M. Piegdoń, Galia Przedalpejska..., s. 199-206.

${ }^{6}$ Układ Pompejusza z popularami oraz Krassusem: App., BCXIII, 121; Plut., Pomp. 21; N. Rogosz, Polityczna rola trybunatu ludowego w Rzymie w latach restauracji sullańskiej (78-70), Katowice 1992, s. 72-117. Najprawdopodobniej był to lipiec 71 roku, przed wyborami: J. Linderski, Rzymskie 
W 70 roku zostali oni konsulami i mimo wzajemnej niechęci oraz rywalizacji doprowadzili do zniesienia najważniejszych ustaw polityczno-ustrojowych dyktatora. Nie oznaczało to, że optymaci stracili wpływ na sprawy państwa. W kolejnych latach najważniejszymi urzędnikami zostawali nadal przedstawiciele tej opcji politycznej, oni też przeważali w senacie ${ }^{7}$.

Spojrzenie na politykę republiki z perspektywy samego tylko Rzymu stanowi jedynie część obrazu skomplikowanej sytuacji wewnętrznej tego państwa. W rzymskich prowincjach oraz w państwach zależnych od republiki pogłębiająca się rywalizacja rzymskich polityków również znajdowała swe odzwierciedlenie. Z takim stanem rzeczy mamy właśnie do czynienia w Galii Przedalpejskiej, gdzie oprócz lokalnych spraw (zmagania z ciągle niezależnymi szczepami alpejskimi, podział mieszkańców na posiadających obywatelstwo rzymskie oraz status latyński) ${ }^{8}$ odbijały się głośnym echem podziały i konflikty w samym Rzymie.

Przede wszystkim wojna ze sprzymierzeńcami radykalnie zmieniła sytuację prawną ludności Galii Przedalpejskiej. Rozwiązania prawne, które republika była zmuszona wprowadzić w trakcie tej wojny, dotyczyły zarówno kolonii latyńskich, jak i rzymskich sprzymierzeńców z Cisalpiny9. Ustawy lex Iulia, lex Plautia Papiria czy lex Cornelia nadawały pełne obywatelstwo rzymskie różnym grupom ludności w Italii, bez względu na miejsce ich zamieszkania. Dotyczyło to także Cisalpiny, gdyż civitas optimo iure uzyskali wszyscy ci, którzy posiadali wcześniej status latyński. Chodziło przede wszystkim o kolonistów z Ariminum, Placencji, Kremony, Bononii, Akwilei i Lukki oraz osadników indywidualnych z obszarów na południe od rzeki Pad. Właśnie tam w III i II wieku republika wysłała ich najwięcej ${ }^{10}$.

zgromadzenia wyborcze od Sulli do Cezara, Kraków 1966, s. 108. Por. M. Piegdoń, Krassus. Polityk niespetnionych ambicji, [wyd. drugie], Kraków 2014, s. 74-78.

7 Zniesienie ustaw: Cic., Verr. 1, 15; Div. Caec. 3, 8; De imp. Cn. Pomp. 62; Sall., Cat. 38, 1; Caes., Bell. Civ. 1, 7; Vell. II, 30; Suet., Iul. 5; Plut., Pomp. 22; App., BCXIII, 121; Cass. Dio XXXVI, 38; F.R. Cowell, Cicero and the Roman Republic, Victoria 1962, s. 224; D. Stockton, The First Consulship of Pompey, „Historia” 1964, 18, s. 210-212; M. Cary, H.H. Scullard, Dzieje Rzymu..., s. 475-476; N. Rogosz, Polityczna rola trybunatu ludowego..., s. 96, 98-104; R. Seager, The Rise of Pompey, w: The Cambridge Ancient History, vol. 9..., s. 224-225; M. Piegdoń, Krassus..., s. 78-86.

${ }^{8}$ Walki Rzymu z plemionami alpejskimi: M. Piegdoń, Galia Przedalpejska..., s. 102-103. Por. uwagi w dalszej części artykułu.

9 E. Bispham, From Asculum to Actium. The Municipalization Italy from the Social War Augustus, Oxford 2007, s. 224-465; M. Piegdoń, Galia Przedalpejska..., s. 106-108, 195-198.

${ }^{10}$ Lex Iulia, lex Plautia-Papiria, lex Cornelia: Cic., Balb. 8, 21; Arch. 4; 5; Fam. 13, 30; Schol. Bob. 6-7 fragm. 175 Stangl.; Sisenna fragm. 119 i 120 Peter; Vell. II, 16, 4; App., BC I, 49, 212; Gell. 3, 4, 3; Licin. 15; E.G. Hardy, Some Problems in Roman History..., s. 47-48; A.N. Sherwin-White, The Roman Citizenship, Oxford 1973, s. 144-156; G. Luraschi, Foedus Ius Latii Civitas..., s. 141-143; J. Zając, Aquileia. Status administracyjny antycznego miasta (III w. p.n.e.-II w. p.n.e.), „Balcanica Posnaniensia” 1984, 3, s. 208-210; E. Gabba, Dallo stato-città allo stato municipale, w: Storia di Roma, t. 2, Torino 1990, s. 704-705; E. Buchi, Roma e la Venetia orientale..., s. 303-304; S. Kendall, 
Cisalpina była zamieszkana nie tylko przez ludność posiadającą status latyński (ta przeważała głównie na terenach odebranych kiedyś eksterminowanym celtyckim Senonom i Bojom oraz deportowanym liguryjskim Apuanom), wśród jej mieszkańców większość stanowiła bowiem ludność autochtoniczna, rzymscy sprzymierzeńcy. Ciężkie zmagania w bellum sociale i chęć zabezpieczenia przez republikę flanki północnej zmusiły rządzących do podjęcia działań mających rozwiązać problem statusu nielatyńskiej ludności Cisalpiny, która nie została objęta ustawą z lat 90$89^{11}$. Zadanie to było bardzo skomplikowane ze względów prawnych, gdyż sprzymierzeńcy zamieszkujący Cisalpinę dzielili się na różne kategorie, a każdą z nich łączył z Rzymem odrębny traktat (foedus). Obok powoli romanizujących się plemion celtyckich i liguryjskich, z którymi Rzym zawarł foedera w pierwszej połowie II wieku, istniały także związki plemienne (np. Wenetowie) oraz osady sprzymierzone, jak Rawenna, Genua czy Pisa, z którymi Rzym łączyły inne porozumienia i sojusze niż z pokonanymi plemionami celtyckimi i liguryjskimi ${ }^{12}$. Realizacją tego celu zajął się konsul 89 roku - Gn. Pompejusz Strabon ${ }^{13}$. Sprawa była pilna, tym bardziej że jakieś kontyngenty wojskowe z Cisalpiny mogły pojawić się w obozach obu stron bellum sociale. Mieszkańcy tego obszaru uczestniczyli w wojnie ze sprzymierzeńcami tylko w niewielkim stopniu, ale istniała obawa, że ich udział się zwiększy ${ }^{14}$. Konsul w ramach swojej provincia otrzymał zadanie uregulowania stosunków polityczno-prawnych w Cisalpinie. Jego władzy podlegały na pewno tereny na północ od rzeki Pad. Natomiast trudno rozstrzygnąć, czy zostały mu podporządkowane obszary na południe od tej rzeki, w tym Liguria, i czy pozostali tam potomkowie Celtów i Ligurów otrzymali status latyński czy też civitas optimo iure na mocy ustaw z lat 90-89. Nie jest to wykluczone ${ }^{15}$. Ten ambitny polityk przeprowadził lex Pompeia

The struggle for Roman citizenship: Romans, allies, and the wars of 91-77 BCE, [Gorgias Press] 2013, s. 353-365, 775-784; J. Dart, The Social War, 91 to 88 BCE, A History of Italian Insurgency against the Roman Republic, Surrey 2015, s. 171-188 contra H. Mouritsen, Italian Unification. A study in Ancient and Modern Historiography, „Bulletin of the Institute of Classical Studies”, Supplement 1998, 70, s. 153-173. Osady w północnej Italii: Hirt., BG VIII, 50; 51; CIL V, 8288 (A) = CIL I², 2198 p. 1093 = ILLRP 538 (A i B) = Imagines 226 (Akwileja); Asc., Pis. 2 (Placencja); Cic., Fam. 13, 13 (Lukka).

${ }_{11}$ M. Piegdoń, Galia Przedalpejska..., s. 106-108, 195-198.

${ }_{12}$ Cic., Balb. 22; Fam. 8, 1, 4 (Rawenna); G. Luraschi, Foedus Ius Latii Civitas..., s. 150-156 contra A.N. Sherwin-White, The Roman Citizenship..., s. 159, przyp. 2. Herakleja i Neapolis: Cic., Balb. 8, 21; Arch. 6; A. Krawczuk, Virtutis ergo. Nadania obywatelstwa rzymskiego przez wodzów Republiki, Kraków 1963, s. 78; L. Morawiecki, Monety miejskie Italii w II i I w. p.n.e., w: Miasto w starożytności, red. L. Mrozewicz, K. Balbuza, Poznań 2004, s. 152-154; M. Piegdoń, Galia Przedalpejska..., s. $179-188$.

${ }_{13}$ Gn. Pompejusz Strabon: Liv., per. 73, 74, 75, 76; Vell. II, 20-21; App., BC I, 63; 66; Oros. V, 19, 10; U. Ewins, Enfranchisement of Cisalpine..., s. 75.

${ }^{14}$ CIL I ${ }^{2}$, 864-866; Sall., Hist. I fragm. 20-22; Plut., Sert. 4; App., BC XIII, 42; 50; A.N. Sherwin-White, The Roman Citizenship..., s. 140.

${ }^{15}$ Część badaczy uważa, że autochtoni z obszarów na południe od Padu nie otrzymali civitas optimo iure: U. Ewins, Enfranchisement of Cisalpine..., s. 77 contra A.N. Sherwin-White, The Ro- 
de Transpadanis, znaną głównie z krótkiej wzmianki komentatora dzieł Cycerona, Askoniusza $^{16}$. Ustawa Pompejusza Strabona dotyczyła przede wszystkim ludności autochtonicznej zamieszkującej tereny na północ od rzeki Pad (Transpadani), ale obszar jego działalności był najprawdopodobniej znacznie szerszy. Świadczy o tym fundacja kolonii, co było najprawdopodobniej jego dziełem, w Alba Pompeja w Ligurii oraz Laus Pompei i na miejscu zniszczonego przez Retów Comum ${ }^{17}$. W tym przypadku status kolonistów latyńskich nadano osadom autochtonów (mniej więcej dwudziestu) sprzymierzonych z Rzymem bez całej skomplikowanej procedury zakładania ich od podstaw, dlatego też określane są one w literaturze współczesnej mianem „kolonii fikcyjnych” ${ }^{18}$. Ich mieszkańcy uzyskali status latyński i prawdopodobnie wszystkie związane z tym prawa. Nie jest też wykluczone, że porządkowanie stosunków wewnętrznych w Cisalpinie, a zwłaszcza na terenach na północ od rzeki Pad, miało szerszy wymiar, gdyż źródła (Pliniusz Starszy) informują o kategorii adtributio. Stanowiła ją ludność autochtoniczna mieszkająca poza dużymi ośrodkami, a która miała zostać przypisana do osad o statusie kolonii latyńskich ${ }^{19}$.

W okresie wojny domowej w latach $83-81$ tereny Cisalpiny były miejscem działań wojennych prowadzonych zarówno przez popularów, jak i zwolenników Sulli ${ }^{20}$. Skutkowało to dużymi zniszczeniami. Źródła nie informują jednak, aby po zwycięstwie Sulli obszar ten został dotknięty poważnymi represjami z jego strony. Znana

man Citizenship..., s. 158-159. Przyznanie przez Pompejusza Strabona obywatelstwa rzymskiego mieszkańcowi Rawenny: Cic., Balb. 22, 50; Fam. 8, 1, 4; A. Krawczuk, Virtutis ergo..., s. 87-89; G. Luraschi, Foedus Ius Latii Civitas..., s. 150-153.

16 Asc., Pis. 2-3.

17 E.G. Hardy, Some Problems in Roman History..., s. 45-47; G. Luraschi, Foedus Ius Latii Civitas..., s. 148-150, 156; H. Galsterer, Aspetti della romanizzazione nella Cisalpina..., s. 170_173; M. Tarpin, Le coloniae lege Pompeia: una storia impossibile?, w: Studi e ricerche sulla Gallia Cisalpina XXVI, Trans Padum... usque ad Alpes. Roma tra il Po e le Alpi: dalla romanizzazione alla romanità. Atti del convegno Venezia 13-15 maggio 2014, a cura di G. Cresci Marone, Roma 2015, s. 214.

${ }_{18}$ G. Luraschi, Foedus Ius Latii Civitas..., s. 157. Działalność Pompejusza Strabona: Vell. II, 20-21; Plut., Pomp. 4; App., BC XIII, 47, 204-207; 50, 216; 52, 227; 63, 283-284; 67, 304; 68, 312; Oros. V, 19, 10; U. Ewins, Enfranchisement of Cisalpine..., s. 75-83; A. Krawczuk, Virtutis ergo..., s. 47-56; G. Luraschi, Foedus Ius Latii Civitas..., s. 177-179.

19 Plin., NH III, 134; CIL V, 7231 = ILS 94; U. Ewins, Enfranchisement of Cisalpine ..., s. 77-78; A. Albertini, Romanità di Brescia antica, Brescia 1978, s. 39-42, 49-50; G. Luraschi, Foedus Ius Latii Civitas..., s. 158-164; 189-214; P. Garnsey, W. Scheidel, Cities, Peasants and Food in Classical Antiquity, Cambridge 1998, s. 45-46 contra L.R. Taylor, The Voting Districts of the Roman Republic, Roma 1960, s. 128. Por. CIL V, 2, 7749; D. Faoro, "Gentes" e "civitates adtributae". Fenomeni contributivi della romanità cisalpina, w: Simblos. Scritti di storia antica, a cura di L. Criscuolo, G. Geraci, A. Bencivenni, Bologna 2015, s. 155-200.

${ }^{20}$ Cic., Verr. 2, 1, 14; Liv., per. 88; Vell. II, 28; Plut., Sull. 27; Pomp. 7-8; App., BC XIII, 80; 86-92; A. Krawczuk, Virtutis ergo..., s. 24-27; T.P. Wiseman, New Men in the Roman Senate, 139 B.C.-A.D. 14, Oxford 1971, s. 256-257; R. Seager, Sulla..., s. 187-197; M. Piegdoń, Galia Przedalpejska..., s. 108-109, 169. 
jest jedynie wzmianka o tym, że przy via Aemilia, między Bononią a Rawenną, powstało Forum Cornelli, którego fundacja jest łączona z osadnictwem dyktatora ${ }^{21}$. Należy także podkreślić, że w tym okresie utworzono lub dokończono proces tworzenia nowej prowincji rzymskiej - Galii Przedalpejskiej (Gallia Cisalpina) ${ }^{22}$. Nie omawiając szczegółów okoliczności jej ustanowienia, należy podkreślić, że wyznaczenie prawnej i rzeczywistej granicy między Italią a Galią Przedalpejską na rzekach Rubikon i Magra ${ }^{23}$ miało istotne znaczenie dla mieszkańców nowej prowincji. W jej ramach funkcjonowała ludność posiadająca różne statusy prawne: obywatele, posiadacze statusu latyńskiego i socii. Szczególnie interesująca jest obecność dużej liczby pełnoprawnych obywateli rzymskich, którzy zamieszkiwali głównie tereny na południe od rzeki Pad (Cispadana) i znaleźli się w nowo utworzonej prowincji.

Dychotomia pomiędzy mieszkańcami prowincji, a więc obywatelami rzymskimi, w południowej jej części, a posiadaczami statusu latyńskiego, osiadłymi głównie za Padem, stała się przyczyną licznych napięć i konfliktów politycznych oraz społecznych, począwszy od lat 70. I wieku aż do 49 roku, kiedy mieszkańcy nieposiadający obywatelstwa rzymskiego - Transpadani - otrzymali civitas optimo iure. Chęć zrównania statusu mieszkańców Galii Przedalpejskiej stała się ważnym argumentem w rozgrywkach politycznych w latach 70., 60. i 50. I wieku wykorzystywanym przez różnych polityków w Rzymie. Aktywność w sprawie zmiany sytuacji prawnej Transpadanów była traktowana najczęściej instrumentalnie. Zainteresowanie tą kwestią kończyło się szybko, gdy politycy osiągali własne cele lub też napotykali na poważny opór w rozwiązaniu tej sprawy ze strony przeciwników politycznych ${ }^{24}$. Działania te trafiały na podatny grunt, gdyż Transpadanowie oka-

${ }_{21}$ Prudent., Perist. 9, 1; A. Krawczuk, Virtutis ergo..., s. 78-79; P.A. Brunt, Italian Manpower 225 B.C.-A.D. 14, Oxford 1971, s. 300-312, 573; J.R. Patterson, Colonization and historiography: the Roman Republic, w: Greek and Roman Colonization. Origins, Ideologies and Interactions, eds. G. Bradley, J.-P. Wilson, Swansea 2006, s. 205-206; M. Piegdoń, Galia Przedalpejska..., s. 169-170.

${ }^{22}$ Licin. 32; CIL I' 739 = V, 863; Sall., Hist. fragm. II 94; 98, 10 M; Cic., Verr. 2, 1, 12-14; Pis. 26, 62; Brut. 92, 318; Liv., per. 77; 90; Vell. II, 20, 1; Val. Max. IX, 7, 2; Plut., Pomp. 16; App., BC XIII, 63, 283; 66, 303; 67, 308; 86, 393; 107, 502; E.G. Hardy, Some Problems in Roman History..., s. 46-49, 232; U. Ewins, Enfranchisement of Cisalpine..., s. 75-76; G. Luraschi, Foedus Ius Latii Civitas..., s. 145-177, 179-189, 207-214; G. Bandelli, Il governo romano nella Transpadana orientale (9042 a.c.), „Antichità Altoadriatiche” 1986, 28: Aquileia nella "Venetia et Histria”, s. 44-46; H. Galsterer, Aspetti della romanizzazione nella Cisalpina..., s. 166-167; J. Zając, Od Wenetów do Rzymian..., s. 25; E. Buchi, Roma e la Venetia orientale..., s. 305-306; T.C. Brennan, The Praetorship..., vol. 2, s. 363-364, 576; V.V. Iasbez, Aquileia dalla seconda guerra istrica all'età postsillana, „Antichità Altoadriatiche" 2003, 54: Aquileia dalle origini alla costituzione del ducato longobardo. Storia Amministrazione - Società, s. 143-145; M. Piegdoń, Galia Przedalpejska..., s. 199-206.

${ }_{23}$ Tac., Ann. XII 23; Sen., Brev. vit. 13, 8; Cass. Dio XLIII, 49, 2; XLIII, 50, 1; N. Purcell, The City of Rome and the "Plebs Urbana" in the Late Republic, w: The Cambridge Ancient History, vol. 9..., s. 649; A. Keaveney, Sulla: The Last Republican, London 2005, s. 193, 200.

${ }^{24}$ Cic., Quinc. 20-21; Sall., Hist. II fragm. 98; Liv., per. 90; Plut., Pomp. 7; 16; 22-27; 43-47; Crass. 12-14; Caes. 5-13; Cic. 10-27; Cat. Min. 16-31; Lucull. 37-39; Front., Strat. 1, 9, 3; App., 
zywali swe niezadowolenie z przyznanego im statusu najprawdopodobniej już na początku lat 70. I wieku' ${ }^{25}$.

W latach 78-70 Galia Cisalpińska była areną konfliktów, które rozgrywały się pomiędzy rządzącymi sullańczykami a dążącymi do obalenia ustawodawstwa Sulli popularami. Pierwszy taki konflikt miał miejsce już rok po śmierci dyktatora, gdy jeden z konsulów, a mianowicie M. Emiliusz Lepidus, przeszedłszy na stronę popularów, próbował restytuować urząd trybunów ludowych z wszystkimi ich uprawnieniami, które zostały im odebrane przez Sullę, a także zapewnić zwrot majątków wywłaszczonym oraz przywrócić prawo zbożowe. Jednak na skutek oporu jego kolegi, Kw. Lutacjusza Katullusa, oraz większości senatu odrzucono wspomniane projekty ustaw. Senat, chcąc pozbyć się Lepidusa z miasta, przydzielił mu jako prokonsulowi zadanie przywrócenia porządku w Fiesole w Etrurii, gdzie doszło do lokalnych rozruchów. Lepidus, otrzymawszy imperium prokonsularne w 77 roku, nie tylko nie stłumił buntu, lecz stanął na jego czele, a jego współpracownik, działający w Galii Narbońskiej M. Juniusz Brutus, udał się do Galii Cisalpińskiej, gdzie zdołał pozyskać zwolenników ${ }^{26}$. Trudno powiedzieć, jakimi hasłami posługiwał się Brutus i czym skłonił mieszkańców tej prowincji do przyłączenia się do ruchu Lepidusa. Być może istotne znaczenie miały w tym przypadku koneksje rodu Emiliuszy, tak zasłużonego dla Galii, oraz jego liczna klientela. Z pewnością dużą rolę odegrał fakt, że Brutus dowodził na tym terenie już wcześniej, w czasie wojny domowej, co pozwoliło mu zjednać sobie licznych zwolenników ${ }^{27}$. Podjęta

BC XIII, 121; XIV, 1-9; Cass. Dio XXXVI-XXXVII; Oros. V, 22, 17; R. Syme, The Roman Revolution, Oxford 1939, s. 28-51; E. Badian, Foreign Clientelae 264-70, Oxford 1958, s. 163, 275-278; E. Gruen, The Last Generation of the Roman Republic, Berkley-Los Angeles-London 1974, s. 6-46; G. Luraschi, Foedus Ius Latii Civitas..., s. 195-196, 346-347; T.P. Wiseman, The Senate and the Populares, 69-60 B.C., w: The Cambridge Ancient History, vol. 9..., s. 327-367; M.P. Rossignani, Gli Aemilii e l'Italia del Nord, w: Splendida civitas nostra. Studiarcheologici in onore di Antonio Frova. Studi e ricerche sulla Gallia Cisalpina, t. 8, Roma 1996, s. 61-75; T.C. Brennan, The Praetorship..., vol. 2, s. 575; A. Ziółkowski, Historia Rzymu, Poznań 2004, s. 337-341; M. Piegdoń, Galia Przedalpejska..., s. 109-117, 170-172, 206-208.

${ }^{25}$ Sall., Hist. I fragm. 20: „[...] citra Padum omnibus lex <in> gratia fuit [...]” (lex Licinia-Mucia z 95 roku); Plut., Sert. 4; App., BC XIII, 42; 50; E. Santamato, Gruppi immigrati e loro gestione a Roma tra II e I sec. a.C., Napoli 2008, s. 143-150; M. Tarpin, Le coloniae lege Pompeia: una storia impossibile?..., s. 205-206.

${ }^{26}$ Liv., per. 90; Plut., Pomp. 16; Oros. V, 22, 17; E. Gruen, The Last Generation..., s. 6-46. M. Juniusz Brutus był też arbitrem w sporze pomiędzy ekwitami z Galii: Cic., Quinc. 20-21. Walczył z Pompejuszem w czasie wojny w 83-82 roku: Plut., Pomp. 7; E. Badian, Foreign Clientelae..., s. 275-278. M. Emiliusz Lepidus otrzymał jako prokonsul Galię Narbońską, a być może także i Galię Cisalpińską: T.C. Brennan, The Praetorship..., vol. 2, s. 575. Sytuacja taka zdarzała się dość często i później. Obie Galie jako prowincje otrzymał G. Aureliusz Kotta w 74 roku, G. Kalpurniusz Pizon w latach 68-64 i Cezar w 59 roku.

${ }^{27}$ E. Badian, Foreign Clientelae..., s. 163, 276; M.P. Rossignani, Gli Aemilii e l'Italia del Nord..., s. 61-75; M. Piegdoń, „Viam fecei...ponteis...poseivei...forum aedisque poplicas heic fecei”. Political 
przez Lepidusa próba marszu na Rzym skończyła się klęską na moście Mulwijskim i pod Cosa. Przywracaniem porządku w Galii Cisalpińskiej zajął się Gn. Pompejusz, który pokonał zwolenników ruchu, a ich przywódcę Brutusa zamknął oblężeniem w Mutynie. Brutus, nie widząc szans na dalszą walkę, skapitulował i został zamordowany przez Pompejusza. Resztki wojsk Lepidusa, który wkrótce zmarł na Sardynii, zostały poprowadzone przez M. Perpernę do Hiszpanii, gdzie zasiliły przeciwników senatu, walczących pod wodzą Kw. Sertoriusza. Pompejusz jeszcze przez jakiś czas przywracał porządek w Galii Przedalpejskiej, dosięgając syna Lepidusa, L. Korneliusza Scypiona Azjatyckiego Emilianusa w Alba Pompeja. Następnie wyruszył przez przełęcze alpejskie i południową Galię do Hiszpanii, aby wesprzeć Kw. Cecyliusza Metellusa Piusa walczącego z Sertoriuszem ${ }^{28}$.

Mimo likwidacji zagrożenia ze strony Lepidusa i jego zwolenników kolejnym namiestnikiem Galii Przedalpejskiej w 74 roku został G. Aureliusz Kotta (nowy zwolennik popularów), który jako konsul 75 roku nie tylko przeszedł z obozu optymatów do popularów, lecz także przeprowadził lex Aurelia de tribunicia potestate, która przywracała trybunom ludowym część uprawnień odebranych im przez Sullę ${ }^{29}$. Namiestnik ten prowadził też jakieś akcje militarne na terenie swojej prowincji, ale szczegóły jego działalności nie są znane ${ }^{30}$.

Pod koniec lat 70. Galia, podobnie zresztą jak cała Italia, stanęła w obliczu poważnego niebezpieczeństwa, jakim było długo lekceważone przez Rzym powstanie niewolników pod wodzą Spartakusa. W 72 roku oddziały niewolnicze, które zamierzały początkowo wydostać się z Italii przez Apeniny i Alpy, spotkały się z oddziałami namiestnika Galii Cisalpińskiej, G. Kasjusza Longinusa. W bitwie pod Mutyną wojska rzymskie poniosły ciężką klęskę, podobnie jak inne próbujące już wcześniej powstrzymać marsz Spartakusa. Kres powstaniu położyła dopiero interwencja M. Licyniusza Krassusa, który po długich zmaganiach pokonał niewolników.

Activity of M. Aemilius Lepidus in Northern Italy, w: Within the Circle of Ancient Ideas and Virtues. Studies in Honour of Professor Maria Dzielska, red. K. Twardowska, M. Salamon, S. Sprawski, M. Stachura, M. Turlej, Kraków 2014, s. 197-208.

${ }_{28}$ Sall., Hist. II fragm. 98; Front., Strat. 1, 9, 3; Plut., Pomp. 16; App., BC XIII, 109; Oros. V, 22, 17; G. Luraschi, Foedus Ius Latii Civitas..., s. 195-196, 346-347; R. Seager, The Rise of Pompey, w: Cambridge Ancient History, vol. 9..., s. 208-209, 212; P. Southern, Pompejusz Wielki, przeł. B. Mierzejewska, Warszawa 2004, s. 52-53; A. Ziółkowski, Historia Rzymu..., s. 337-338; K. Bringmann, Historia republiki..., s. 208-210. Oprócz Mutyny punktem oporu było także Reggium Lepidum: Oros. V, 22, 17; L. Malnati, Reggio Emilia in età repubblicana, w: Lepidoregio. Testimonianze di età romana a Reggio Emilia, a cura di G. Ambrosetti, R. Macellari, L. Malnati, Reggio Emilia 1996, s. 41; 43. L. Korneliusz Scypion Azjatycki Emilianus: G. Luraschi, Foedus Ius Latii Civitas..., s. $369-375$.

${ }^{29}$ CIL I'2 739 = V 863; Sall., Hist. fragm. II, 98, 10 M; Cic., Pis. 26, 62; Brut. 92, 318; J. Zając, Od Wenetów do Rzymian. Studia epigraficzno-antroponomastyczne (I w. p.n.e.-I w. n.e.), Toruń 1991, s. 25; T.C. Brennan, The Praetorship..., vol. 2, s. 576.

${ }^{30}$ Cic., Brut. 92, 318. 
Część niewolników, która uciekła na północ, być może do zachodniej części Galii Cisalpińskiej lub Etrurii, została pokonana przez powracającego z Hiszpanii Pompejusza ${ }^{31}$.

Sytuacja polityczna w Rzymie po 70 roku była więc niezwykle dynamiczna. Pompejusz i Krassus, konsulowie 70 roku, byli skonfliktowani i nie ufali sobie do tego stopnia $^{32}$, że w obawie o swoją pozycję w Mieście pozostali w nim, nie zdecydowali się na obranie prowincji ${ }^{33}$. Pompejusz dążył do osiągnięcia dowództwa, które dawałoby mu nadzwyczajne uprawnienia, tj. imperium extraordinae. Nie było to możliwe w 69 roku, gdyż mimo obalenia ustawodawstwa sullańskiego i wzrostu roli popierających go populares urzędy konsulów sprawowali nieprzychylni mu optymaci Kw. Hortensjusz Hortalus i Kw. Cecyliusz Metellus Kretykus ${ }^{34}$. Sytuacja zmieniła się dopiero w 68 roku, gdy urzędy pretorskie prawdopodobnie zdobyli trybunowie ludowi G. Licyniusz Macer i L. Kwinkcjusz. Właśnie Kwinkcjusz skrytykował zbyt szerokie uprawnienia Lukullusa, pozostającego na Wschodzie i prowadzącego z ramienia senatu wojnę z Mitrydatesem VI Eupatorem. Atak na Lukullusa był nie tylko inicjatywą jednego z trybunów, lecz szerszą kampanią. Rozporządzenia Lukullusa na Wschodzie szczególnie mocno dotknęły bowiem interesów finansowych publikanów, którzy postarali się, aby ich sprzymierzeńcy w Rzymie, ekwici, rozpoczęli starania najpierw o ograniczenie jego uprawnień, a następnie o pozbawienie go sprawowanego dowództwa. Kolejnymi niezadowolonymi byli żołnierze Lukullusa, którzy służyli jeszcze w armii L. Waleriusza Flakkusa i G. Flawiusza Fimbrii w latach 80., podburzani przez szwagra wodza, P. Klaudiusza Pulchra (Klodiusz). Prawdopodobnie za niektórymi z tych działań stał Pompejusz, który - jak wspomniano dążył do zdobycia imperium maius i wzmocnienia swojej pozycji przez dalsze sukcesy militarne. Oprócz tego, że Lukullus był jednym z głównych optymatów rywalizującym od dawna $\mathrm{z}$ Pompejuszem, był on również narażony na ataki trybunów, którzy chętnie w interesie bądź popularów, bądź Pompejusza odebraliby mu jego uprawnienia. W wyniku ataków Kwinkcjusza najpierw pozbawiono Lukullusa Cylicji, a później Pontu i Bitynii. Nowi namiestnicy tych prowincji jednak nie tylko nic nie zrobili, aby przeciwstawić się nowej ofensywie Mitrydatesa, lecz także nie

${ }^{31}$ Sall., Hist. III fragm. 94; Liv., per. 95-97; Plut., Crass. 8-11; Pomp. 21; App., BC XIII, 116-120; Flor. II, 8; R. Kamienik, Odwrót Spartakusa i fiasko przeprawy na Sycylię, „Annales Universitatis Mariae Curie-Skłodowska" 1960, sect. F, 15, s. 1-20; Idem, Studia nad topografia powstania Spartakusa, „Annales Universitatis Mariae Curie-Skłodowska” 1973, sect. F, 28, passim.

32 Plut., Crass. 7; 12; Pomp. 22; 23; App., BC XIII, 121; B.A. Marshall, Crassus. A Political Biography, Amsterdam 1976, s. 52-54; A.M. Ward, Marcus Crassus and Late Roman Republic, Columbia 1977, s. 103-104; P. Southern, Pompejusz..., s. 71; M. Piegdoń, Krassus..., s. 73 -78.

${ }^{33}$ J. Iluk, Kilka uwag o roli M. Liciniusza Krassusa w I triumwiracie, „Zeszyty Naukowe Uniwersytetu Gdańskiego" 1971, sect. H, s. 5; M. Piegdoń, Krassus..., s. 80-82.

${ }^{34}$ Optymaci odgrywali znaczącą rolę w senacie: A.M. Ward, Marcus Crassus..., s. 14-19; M. Piegdoń, Krassus..., s. 86-87. Rola senatu: N. Rogosz, Polityczna rola senatu w Republice Rzymskiej w latach 59-55, Katowice 2004. 
pomogli Lukullusowi, który próbował odeprzeć króla Pontu. Zarzucano im więc, że zdobyli część uprawnień Lukullusa, aby przekazać je Pompejuszowi ${ }^{35}$.

Wcześniej postanowiono jednak uporać się z uciążliwym procederem piractwa, które utrudniało m.in. zaopatrywanie Italii i Rzymu w zboże. A. Gabiniusz, trybun 67 roku i stronnik Pompejusza, wprowadził pod obrady projekt prawa przyznającego dowództwo w wojnie z piratami. Szerokie uprawnienia, które dawała proponowana ustawa, miały być przekazane jedynie jednemu z byłych konsulów, który miał zostać wodzem. Z wystąpienia trybuna Gabiniusza wynikało, że dowódcą powinien zostać Pompejusz. Senat niemal w całości oponował przeciwko temu, ale musiał ustąpić, zastraszony przez wspierający Pompejusza plebs. Tylko G. Juliusz Cezar, młody senator, poparł projekt ustawy Gabiniusza ${ }^{36}$. Konsul G. Kalpurniusz Pizon za sprzeciw wobec projektu przyszłej lex Gabinia omal nie został zlinczowany przez tłum. Pompejusz starał się pokazać, że nie zależy mu na przejęciu dowództwa w planowanej wojnie z piratami. Była to jednak z jego strony jedynie gra ${ }^{37}$. Mimo wszystko optymaci starali się zablokować uchwalenie ustawy poprzez intercesję oddanych sobie trybunów L. Trebeliusza i L. Roscjusza Othona. Wtedy Gabiniusz stwierdził, że pozbawi Trebeliusza urzędu i jednocześnie rozpoczął głosowanie nad projektem. Drugi z trybunów, Othon, próbował sugerować wybór innego wodza. W tym samym duchu wypowiadał się również dopuszczony do głosu przywódca optymatów, Kw. Lutacjusz Katullus, który ostrożnie i bez skutku dawał do zrozumienia, że dobrze byłoby wysłać kogoś innego w miejsce Pompejusza ${ }^{38}$. Lex Gabinia de bello piratico dawała Pompejuszowi szerokie uprawnienia i ogromne siły do walki z piratami na całym Morzu Śródziemnym. Już po trzech miesiącach udało mu się oczyścić z nich większą część morskiego terytorium ${ }^{39}$.

${ }_{35}$ Cic., Cluent. 40, 110; 112; Sall., Hist. fragm. (Maur.) 3, 48; 11; Plut., Lucull. 5; 33-35; Cass. Dio XXXVI, 14; 15-17; B. Twyman, Metelli, Pompeius and Prosopography, w: Aufstieg und Niedergang der römischen Welt. Geschichte und Kultur Roms im Spiegel der neueren Forschung, Bd. 1, hrsg. H. Temporini, Berlin-New York 1972, s. 864-871; A. Keaveney, Lukullus, przeł. A. Ziółkowski, Warszawa 1998, s. 126-132; S. Mrozek, Ostatni wódz republiki, Gdańsk 2003, s. 70-88. Kw. Marcjusz Reks został namiestnikiem Cylicji. Mn. Acyliusz Glabrion został namiestnikiem Pontu i Bitynii (konsul 68 roku).

${ }^{36}$ Plut., Pomp. 25. Opozycja senatu: Cic., Att. 5, 21.

${ }^{37}$ Cic., Sest. 53; Plut., Pomp. 25; Cass. Dio XXXVI, 23; 25-27. A. Gabiniusz został później legatem Pompejusza w jego walkach na Wschodzie.

${ }^{38}$ Weto: Cic., Corn. fragm. 31; Plut., Pomp. 25; Cass. Dio XXXVI, 24; 31-37. Podobnie postąpił w 133 roku Tyb. Semproniusz Grakchus z trybunem M. Oktawiuszem: Plut., Tib. Gracch. 15. Gabiniusz nie odsunął jednak Trebeliusza, był to tylko manewr, który miał zastraszyć trybuna: K. Bringmann, Historia republiki..., s. 271. Późniejsza współpraca z Krassusem mogła sugerować, że Roscjusz Othon miał na myśli Krassusa jako drugiego wodza: A.M. Ward, Marcus Crassus..., s. 114-115; M. Piegdoń, Krassus..., s. 88-91.

${ }_{39}$ Plut., Pomp. 26-29; App., Mithr. 95-96; Flor. I, 41; Cass. Dio XXXVI, 37; R. Seager, Pompey the Great. A Political Biography, Oxford 2002, s. 45-49; A. Goldsworthy, Cezar. Życie giganta, przeł. J. Lang, Warszawa 2007, s. 185-190; P. de Souza, Piraci w świecie grecko-rzymskim, przeł. K. Kuraszkiewicz, Zakrzewo 2008, s. 202-214. 
Konflikty pomiędzy senatem a popularami i popierającym ich Pompejuszem pojawiły się także w roku następnym. Zwycięstwo w wojnie z piratami i działalność nowego trybuna ludowego G. Maniliusza dały Pompejuszowi upragnione przez niego dowództwo w wojnie na Wschodzie. Trybun przeprowadził ustawę lex Manilia, która oddawała w ręce Pompejusza, mimo jego nieobecności w Rzymie, prowincje wschodnie - Bitynię i Pont, Cylicję oraz cały teren, na którym toczyły się walki z królem Pontu. Dotychczasowy ich namiestnik, Lukullus, powrócił po ośmiu latach namiestnictwa do Rzymu. Oczywiście przeciwko nadaniu Pompejuszowi tak szerokich uprawnień wystąpiła opozycja w senacie z Kw. Lutacjuszem Katullusem oraz Kw. Hortensjuszem Hortalusem na czele. Jednak za przekazaniem Pompejuszowi dowództwa na Wschodzie opowiedziała się w senacie część konsularów z P. Serwiliuszem Watią Izauryckim, G. Skryboniuszem Kurionem, G. Kasjuszem Warusem i Gn. Korneliuszem Lentulusem. Projekt ten znów poparł G. Juliusz Cezar, a także starający się o konsulat M. Tulliusz Cyceron. Pompejuszowi udało się więc uzyskać upragnione dowództwa w konfliktach z piratami i królem Pontu ${ }^{40}$, ale w samym Rzymie jego zwolennicy, głównie popularowie, nie zdominowali sceny politycznej. Optymaci stali się poważną siłą w Mieście i po wyjeździe Pompejusza na Wschód - dzięki przewadze w senacie i kontrolowaniu większości urzędów mieli decydujący wpływ na wydarzenia w Rzymie w latach 60 .

Opowiadający się po stronie Pompejusza i związany rodzinnie oraz politycznie z popularami Cezar piął się tymczasem powoli po szczeblach cursus honorum. W 69 lub 68 roku został wybrany na urząd kwestora. Urząd swój miał sprawować w Hiszpanii Dalszej przy namiestniku pro praetore G. Antystiuszu Wetusie, który również był związany z popularami ${ }^{41}$. Jednakże Cezar w Hiszpanii zjawił się późno, gdyż zmarła najpierw jego ciotka Julia, żona G. Mariusza, a następnie jego żona Kornelia. Ich pamięć Cezar uczcił w czasie uroczystości pogrzebowych, które stały się także okazją do jego stanowczych deklaracji politycznych - w trakcie uroczystości pokazane zostały wizerunki G. Mariusza ${ }^{42}$. W swojej prowincji nie zabawił zresztą długo, krótko po przybyciu miał wyruszyć właśnie do Galii Przedalpejskiej, gdzie zaczął prowadzić agitację wśród niezadowolonych ze swojego

${ }^{40}$ Cic., Leg. Man., passim; Vell. II, 31-32; Plut., Pomp. 30; Cic. 9; App., BC XIV, 2-3; Mithr. 50; Cass. Dio XXXVI, 43; M. Piegdoń, Krassus..., s. 92-93. Opozycja Katullusa: N. Rogosz, Polityczna rola senatu..., s. 32, 36, 39, 41. Por. A. Keaveney, Lukullus..., s. 133-134.

${ }^{41}$ Kwestura Cezara w 69 lub 68 roku: Bell. Hisp. XLII, 1; Vell. II, 43, 4; Plut., Caes. 5; Suet., Iul. 6-8; Cass. Dio XXXVII, 52, 2; XLI, 24, 2. Por. kwestia datowania namiestnictwa Antystiusza Wetusa w Hiszpanii: T.C. Brennan, The Praetorship..., vol. 2, s. 514-515; 754; N. Rogosz, Wokót datacji kwestury G. Juliusza Cezara, w: Florilegium. Studia ofiarowane Profesorowi Aleksandrowi Krawczukowi z okazji dziewięćdziesiątej piątej rocznicy urodzin, red. E. Dąbrowa, T. Grabowski, M. Piegdoń, Kraków 2017, s. 221-232.

${ }^{42}$ Suet., Iul. 6, 1; Plut., Caes. 5, 1-3; N. Rogosz, Wokót datacji kwestury G. Juliusza Cezara..., s. $224-225$. 
statusu mieszkańców kolonii latyńskich ${ }^{43}$. Zaskakuje fakt, że sam Cezar, polityk o niezbyt wielkim wówczas znaczeniu, z własnej inicjatywy opuścił wyznaczone mu miejsce, gdzie miał realizować swoje provinciae, i zjawił się na obszarze, który był w gestii innego urzędnika wysokiej rangi - konsula 68 roku i równocześnie namiestnika obu Galii (Przedalpejskiej i Narbońskiej) - G. Kalpurniusza Pizona. Nota bene zaciekle przeciwstawiającego się popularom i Pompejuszowi w Rzymie. Jest mało prawdopodobne, że Cezar działał wyłącznie z własnej inicjatywy. Byłoby to bardzo niebezpieczne i mogłoby doprowadzić do zakończenia jego krótkiej kariery ${ }^{44}$. Miejsce jego aktywności prawdopodobnie też nie zostało wybrane przypadkowo. Szkodził optymacie Pizonowi, przeciwnikowi Pompejusza Wielkiego, w osadach, które uzyskały status latyński lub/i zostały ufundowane przez ojca tego ostatniego Gn. Pompejusza Strabona w 89 roku. Można się domyślać, że miasta te miały bliskie związki klienckie z Pompejuszem Wielkim ${ }^{45}$. Agitacja Cezara była na tyle skuteczna, a nastroje wśród mieszkańców na tyle gorące, że w Rzymie zdecydowano o pozostawieniu w Italii legionów, które były przygotowane do wysłania do Cylicji ${ }^{46}$. Dopiero wtedy Cezar zrezygnował ze swoich działań i wrócił do Rzymu ${ }^{47}$.

Nie tylko zresztą Cezar próbował pozyskać mieszkańców północnej Italii dla swoich planów politycznych w Rzymie. W 65 roku, a więc po wyjeździe Pompejusza Wielkiego, jego rywal i również polityk związany z opcją popularów - cenzor M. Licyniusz Krassus, podjął próbę nadania obywatelstwa Transpadanom. Był to poważny akt, gdyż to działanie mogło pozwolić mieszkańcom zza Padu stać się formalnie obywatelami rzymskimi. Najprawdopodobniej ta akcja została mocno

${ }^{43}$ Suet., Iul. 8. Swetoniusz jasno stwierdzał, że agitacją Cezara były objęte tylko kolonie latyńskie, a nie wszyscy Transpadanowie. Można wyraźnie stwierdzić, że w grę mogły wchodzić tylko ośrodki, które otrzymały status latyński (tzw. kolonie fikcyjne) na podstawie lex Pompeia de Transpadanis z 89 roku i/lub kolonie, które Gn. Pompejusz Strabon, ojciec Pompejusza Wielkiego, ufundował w tym okresie.

${ }^{44}$ Cic., Att. 1, 1, 2; A. von Premerstein, Legatus, w: Real-Encyclopädie der classischen Altertumswissenschaft, Bd. 23, Stuttgart 1924, szp. 1135-1136.

${ }^{45}$ Jest to dość daleko idące przypuszczenie, ale nie można tego wykluczyć. Przekaz Swetoniusza (Iul. 8) jest na tyle lakoniczny, że nie pozwala dowiedzieć się więcej. Można domyślać się, że sam Cezar mógł już wtedy zacząć budować jakieś związki klienckie z przedstawicielami tych osad, które mocno wspierały go później w okresie jego długiego namiestnictwa i w czasie wojny domowej z Pompejuszem w latach 40.: Sall., Cat. 49; Cic., Att. 5, 2; Flacc. 39; Hirt., BG VIII, 50—52; Plut., Caes. 27. Być może wpływ na taki stosunek do mieszkańców tych terenów miał fakt, że jednym z nauczycieli Cezara był M. Antoniusz Gnifo, z pochodzenia Gal. Trudno też powiedzieć, w których osadach był aktywny, czy we wszystkich, czy też w wybranych? Związane to jest z tym, że nie wiadomo, jak długo przebywał w Galii Przedalpejskiej: N. Rogosz, Wokół datacji kwestury G. Juliusza Cezara..., s. 223-229.

${ }^{46}$ Suet., Iul. 8; M. Piegdoń, Caesar et Transpadani..., s. 259-270; Idem, Galia Przedalpejska..., s. 111-112. Zastanawia, dlaczego to konsulowie w Rzymie musieli uspokoić sytuację w prowincji, która miała przecież namiestnika i trzy legiony, wstrzymując wyjazd do Cylicji wojsk rzymskich.

${ }^{47}$ Suet., Iul. 8-9. 
rozpropagowana, gdyż Transpadanowie pojawili się w dużej liczbie w Rzymie. Jako posiadacze statusu latyńskiego mieli oni możliwość uczestniczenia w zgromadzeniach w Rzymie na mocy przysługującego im prawa. Siła tego wystąpienia oraz znaczenie, jakie mieli wyborcy z prowincji na zgromadzeniu, skłoniła optymatów do działań przeciwko akcji Krassusa. Drugi z cenzorów 65 roku, a mianowicie Kw. Lutacjusz Katullus, nie zgodził się na wpisanie ich na listy, co spowodowało kryzys, gdyż Krassus nie chciał zrezygnować ze swojego postulatu i lustrum nie zostało w tym roku przeprowadzone. Mało tego, zwolennik optymatów, trybun ludowy 65 roku, G. Papiusz, przeprowadził prawo nakazujące wszystkim nieposiadającym obywatelstwa opuszczenie Rzymu, co było wymierzone głównie w Transpadanów, którzy mieli status latyński ${ }^{48}$.

Sytuacja w Rzymie nie uspokoiła się po wyjeździe Pompejusza, a wręcz przeciwnie - stała się jeszcze bardziej napięta. Z jednej strony brak wodza oznaczał, że optymatom ubył silny i wpływowy przeciwnik, który mógł jednoczyć ich wrogów - popularów. Z drugiej strony w Rzymie pozostał Krassus, który zamierzał wykorzystać nieobecność swego rywala do uzyskania jak największych wpływów w Mieście. Opierał się przy tym na popularach, ale także negocjował swoje interesy z innymi grupami, w tym z częścią optymatów. Posiadając silną klientelę wśród różnych środowisk i ciągle ją poszerzając, Krassus mógł realizować swoje cele polityczne ${ }^{49}$. Pierwszą inicjatywą, w której prawdopodobnie uczestniczył po wyjeździe Pompejusza, było poparcie dla porozumienia P. Autroniusza Petusa i P. Korneliusza Sulli, którzy w wyniku oskarżenia o przekupstwa wyborcze zostali skazani i nie mogli pełnić urzędów konsulów w 65 roku. Poparł również wtedy L. Sergiusza Katylinę i Gn. Kalpurniusza Pizona. Porozumienie tych wszystkich polityków, nazywane często tzw. pierwszym sprzysiężeniem Katyliny albo spiskiem Pizona, miało na celu obalenie konsulów L. Aureliusza Kotty i L. Manliusza Torkwatusa, którzy zostali wybrani na miejsce odsuniętych. Po obaleniu konsulów miało dojść do rzezi senatu 1 stycznia 65 roku lub 5 lutego tegoż roku oraz do wyboru na dyktatora właśnie

${ }^{48}$ Plut., Crass. 13; Cat. Min. 16; Cass. Dio XXXVII, 9, 3-5; E.G. Hardy, Some Problems in Roman History..., s. 61-67; B. Marshall, Crassus..., s. 65, 72, 81; A.M. Ward, Marcus Crassus..., s. 128-129; G. Luraschi, Foedus Ius Latii Civitas..., s. 87, 236-237, 348-349, 388-389; G. Bandelli, Il governo romano nella Transpadana orientale..., s. 50, 53; T.C. Brennan, The Praetorship..., vol. 2, s. 577; M. Piegdoń, Galia Przedalpejska..., s. 111-112, 206; Idem, Krassus..., s. 107-108. Rolę mieszkańców prowincji w zgromadzeniach podkreśla Cyceron (Att. 1, 1, 2: „videtur in suffragiis multum posse Gallia"); T.P. Wiseman, New Men in the Roman Senate..., s. 139-140.

${ }^{49}$ Cic., Fam. 5, 2; Off. 1, 25; Brut. 66, 233; Mur. 23, 48; Sall., Iug. 41, 7; Plut., Crass. 7; 35 (2); Cass. Dio XXXVII, 56; L.T. Błaszczyk, Ze studiów nad senatem rzymskim w okresie schyłku Republiki, Łódź 1965, s. 77-95; F.E. Adcock, Marcus Crassus. Milionnaire, Cambridge 1966, s. 10-11; E.J. Parrish, Crassus' New Friends and Pompey Return, „Phoenix” 1973, 27, s. 357-360; A.M. Ward, Marcus Crassus..., s. 75-77; N. Rogosz, Polityczna rola senatu..., s. 33, 37, 38, 40-41, 46-47; E. Deniaux, Patronage, w: A Companion to the Roman Army, ed. P. Erdkamp, Oxford 2007, s. 401-420; M. Piegdoń, Krassus..., s. 93-96. 
Krassusa, a na dowódcę jazdy - Cezara ${ }^{50}$. W rzeczywistości trudno powiedzieć, czy istniał taki spisek i czy powiązani z nim byli Krassus i Cezar. Pomijając okoliczności tego sprzysiężenia oraz rozważania na temat jego wiarygodności ${ }^{51}$, należy zwrócić uwagę na informację o bliskiej współpracy M. Licyniusza Krassusa z Cezarem. Ten ostatni po wyjeździe Pompejusza zaczął bowiem współdziałać z jego rywalem, Krassusem. Cezar, zdolny mówca, pochodzący z arystokratycznej rodziny oraz spokrewniony z dawnymi przywódcami popularów, Mariuszem i Cynną, znakomicie się nadawał do realizacji celów Krassusa, których uwieńczeniem miała być jego dominująca pozycja w państwie jako princeps civitatis. Cezar natomiast widział w porozumieniu $\mathrm{z}$ bogatym i wpływowym Krassusem możliwość sięgnięcia po najwyższe urzędy $w$ republice oraz spłaty zaciągniętych długów ${ }^{52}$. Jednym z pierwszych efektów współpracy Cezara z Krassusem mogły być wspomniane wydarzenia z 65 roku.

Właśnie w tym roku Krassus zaczął współdziałać również z Gn. Kalpurniuszem Pizonem. Pochodził on z plebejskiego rodu Kalpurniuszy i w połowie lat 60. zaczynał swoją karierę polityczną, uzyskując w 66 roku urząd kwestora ${ }^{53}$. Krassus po otrzymaniu przez Pompejusza rozległych uprawnień na Wschodzie także starał się znaleźć prowincję, jeśli nie dla siebie, to dla któregoś ze swoich klientów. Oprócz sieci jego rozległych powiązań w Rzymie i olbrzymich bogactw dałaby mu ona, poprzez związanego z nim namiestnika, możliwość posiadania armii - ważnego atutu w przyszłych rozgrywkach z Pompejuszem. Być może dla Krassusa istotne były powiązania Pizona z Hiszpanią. Sam M. Krassus ukrywał się tam w latach 80 . I wieku przed czystkami popularów, prawdopodobnie miał także licznych klientów w Hiszpanii, związanych jeszcze z jego ojcem, który był namiestnikiem prowincji ${ }^{54}$. Pizon, podobnie jak i Cezar, który także w 65 roku został edylem, widział w związku z wpływowym Krassusem możliwość zrobienia błyskotliwej kariery. Zwraca uwage fakt, że żaden z konsulów czy pretorów nie otrzymał Hiszpanii Bliższej jako prowincji prokonsularnej bądź propretorskiej, a otrzymał ją właśnie tylko kwestor Pizon.

50 Cic., Cat. 1, 6; Mur. 37; Sull. 4; Asc. 92 C; Sall., Cat. 18; Suet. Iul. 9; Cass. Dio XXXVI, 44; R. Seager, The First Catilinarian Conspiracy, „Historia” 1964, 13, s. 338-342; A.M. Ward, Marcus Crassus..., s. 119, 138-144.

51 F.B. Marsh, A History of the Roman World 146-30 B.C., London 1963, s. 162; R. Seager, The First Catilinarian..., s. 338-347; M. Piegdoń, Krassus..., s. 99-102. Szczególną rolę spełnia tu fragment mowy Cic., Sull. 4 (z 62 roku), w którym Cyceron przyznawał, że nic pewnego o sprzysiężeniu z 66 roku nie wiedział, co jest sprzeczne z tym, co mówił w swoich poprzednich mowach (Cat. I, 6; Mur. 37).

52 Suet., Iul. 10; Cass. Dio XXXVII, 8; T.J. Cadoux, Marcus Crassus: A Revaluation, „Greece\&Rome” 1956, 3 (2), s. 156; A.M. Ward, Marcus Crassus..., s. 125-127; M. Piegdoń, Krassus..., s. $105-106$.

53 Sall., Cat. 19; Suet., Iul. 9; Cass. Dio XXXVI, 44; E. Badian, Foreign Clientelae..., s. 278-279, $312,316$.

54 Plut., Crass. 4; 5; E. Badian, Foreign Clientelae..., s. 316; F.E. Adcock, Marcus Crassus..., s. 1; A.M. Ward, Marcus Crassus..., s. 49; M. Piegdoń, Krassus..., s. 31, 35. 
Nie wiadomo, dlaczego zdecydowano się nadać byłemu kwestorowi prowincję Hiszpanię Bliższą jako namiestnikowi pro praetore $e^{55}$.

Wydarzenie to jest ważne z jeszcze jednego względu. Według Swetoniusza Pizon i Cezar w porozumieniu z Krassusem mieli doprowadzić do rozruchów, które miały objąć Rzym i prowincję Hiszpanię Bliższą. Cezar miał znów szukać wsparcia dla swojej akcji w północnej Italii, gdzie poprzeć go mieli Transpadanowie, a także tajemniczy „Ambranos”56. Zdobycie wsparcia w prowincji Gallia Cisalpina nie było dla Cezara wielkim problemem; po pierwsze, miał on już związki z niektórymi jej mieszkańcami, o czym wcześniej wspomniano; po drugie, sytuacja wśród mieszkańców tej prowincji posiadających status latyński i tak była mocno napięta w 65 roku, w związku z akcją cenzora M. Licyniusza Krassusa, który próbował ich wpisać na listy obywateli rzymskich. Dużo istotniejsza wydaje się odpowiedź na pytanie, kim byli owi tajemniczy „Ambranos”, których Swetoniusz wymienia obok „Transpadanos”. W literaturze pojawiło się wiele teorii na ten temat. Część badaczy uważała, że owi „Ambranos” to germańscy Ambronowie, inni widzieli w nich szczep celtycki lub liguryjski, ale także Umbrów lub nawet plemię pochodzenia sabińskiego. Pojawiła się też teoria wywodząca nazwę plemienia od nazwy rzeki Lambrus (dziś Lambrano), którą umiejscawiano na wschód od Comum i na północ od rzeki Pad ${ }^{57}$. Wydaje się, że należy odrzucić teorie o zaalpejskim pochodzeniu „Ambranos”, a także nie wiązać ich z germańskimi Ambronami, którzy według źródeł zostali rozgromieni wraz z Teutonami przez Mariusza pod Aquae Sextiae w $102 \mathrm{roku}^{58}$. Trudno brać poważnie pod uwagę teorie wiążące ich z Umbrami lub innymi ludami ze środkowej Italiii ${ }^{59}$. Wydaje się, że wzmiankowani przez Swetoniusza „Ambranos” pochodzili z Galii Przedalpejskiej i mogli być szczepem liguryjskim, który rzeczywiście pojawia się jako rzymscy socii w bitwie pod Aquae Sextiae w 102 roku, noszącym nazwę podobnie brzmiąca jak Ambronowie walczący po

${ }_{55}$ ILS 875; R. Seager, The First Catilinarian..., s. 346.

${ }^{56}$ Suet., Iul. 9: „[...] etiam cum Gnaeo Pisone adulescente, cui ob suspicionem urbanae coniurationis prouincia Hispania ultro extra ordinem data sit; pactumque ut simul foris ille, ipse Romae ad res nouas consurgerent, per $\uparrow$ Ambranos et Transpadanos; destitutum utriusque consilium morte Pisonis”. Por. M. Deutsch, Caesar and the Ambrones: (Suetonius Iulius ix. 3), „Classical Philology” $1921,16,3$, s. $256-259$.

57 Starsze teorie, począwszy od XVIII wieku, na temat „Ambranos” zebrał Monroe Deutsch (Caesar and the Ambrones: (Suetonius Iulius ix. 3), „Classical Philology” 1921, 16, 3, s. 256-259).

${ }^{58}$ Liv., per. 68; Strab. 4, 4, 2 (183); Festus, ep. 17; Veget., Re Militar. III, 10; Oros. V, 16; Plut., Mar. 15; 19; 20; Cass. Dio XLIV, 42 i I, 24; Eutrop. V, 1.

${ }_{59} \mathrm{Na}$ przykład na terenie Etrurii mamy do czynienia z nazwą rzeki Ambro, ale nazwy typu Ambro czy Umbro były dość częste w Italii: Plin., NH III, 51; A.J. Toynbee, Hannibal's Legacy. The Hannibalic War's Effects on Roman Life, vol. 1, London 1965, s. 94-95; G. Bradley, Ancient Umbria. State, Culture, and Identity in Central Italy from the Iron Age to the Augustan Era, Oxford 2000, s. 24-25. Por. M. Deutsch, Caesar and the Ambrones..., s. 257. 
stronie Teutonów ${ }^{60}$. Możliwe jest też powiązanie tej grupy z terenami leżącymi na wschód od Comum. Obszary te nie były bowiem całkowicie celtyckie, ponieważ w materiale archeologicznym i epigraficznym znaleźć można elementy nieceltyckie. Nazwa tej grupy rzeczywiście mogła pochodzić od hydronimu Lambrus, gdyż w Cisalpinie występuje więcej tego typu przykładów ${ }^{61}$. Późniejsze związki Cezara z tymi terenami mogą również potwierdzać, że właśnie stąd mogli wywodzić się "Ambranos”. W 58 roku jako namiestnik ufundował on najprawdopodobniej colonia civium Romanorum w Comum (Novum Comum), doskonale orientując się w panujących miejscowych stosunkach (zagrożenie ze strony plemion alpejskich) ${ }^{62}$.

Jednakże cała inicjatywa zakończyła się niepowodzeniem. Rządy kogoś związanego z Krassusem były bardzo niebezpieczne dla Pompejusza. Pizon został zamordowany w dość tajemniczych okolicznościach, gdyż miał być zbyt okrutny dla ludności swojej prowincji ${ }^{63}$. Można się domyślać, że także inicjatywa Cezara poruszenia mieszkańców północnej Italii skończyła się tym samym. Cezar nie poniechał jednak działań na rzecz Transpadani i od tego momentu odwoływał się do ich poparcia w różnych późniejszych akcjach politycznych z lat 50. i 40. I wieku.

${ }^{60}$ Podbój rzymski Comum i okolic: Liv. XXXIII, 36-37; Fasti Capitolini 102 a. DLVII Degrassi; A.J. Toynbee, Hannibal's Legacy..., vol. 2, s. 270; G. Luraschi, Foedus Ius Latii Civitas..., s. 130, 132; M. Piegdoń, Chłosta mieszkańca Novum Comum a sprawa statusu osady, w: Przemoc w świecie starożytnym. Źródła - struktury - interpretacje, red. D. Słapek, I. Łuć, Lublin 2017, s. 240-242; $\mathrm{S}$. Bourdin, Les peoples de l'Italie préromaine. Identités, territoires et relations inter-ethniques en Italie centrale et septentrionale (VIII $-I^{e r}$ s. av. J.-C.), Rome 2012, s. 95, 423, 724-725; M. Tarpin, Le coloniae lege Pompeia: una storia impossibile?..., s. 200-201. Por. M. Deutsch, Caesar and Ambrones..., s. 257-258.

${ }^{61}$ M. Deutsch, Caesar and Ambrones..., s. 257. Struktura etniczna mieszkańców terenów podalpejskich, w tym również Comum: Strab. 4, 6, 6 (204); G. Luraschi, Foedus Ius Latii Civitas..., s. 103; S. Bourdin, Les peoples de l'Italie préromaine..., s. 93; M. Piegdoń, Chłosta mieszkańca Novum Comum..., s. 240-242. Do teorii, że nazwa Ambranos pochodziła od nazwy rzeki Lambrus powrócił później G. Luraschi, Foedus Ius Latii Civitas..., s. 347-349, 375-376.

${ }^{62}$ Cic., Att. 5, 11; Strab. 5, 1, 6 (213); Plut., Caes. 29; Suet., Iul. 28; App., BC II, 26, 98; E.G. Hardy, Some Problems in Roman History..., s. 126-149; U. Ewins, Enfranchisement of Cisalpine..., s. 86-87; G. Luraschi, Foedus Ius Latii Civitas..., s. 137, 340, 404-506; M. Piegdoń, Chłosta mieszkańca Novum Comum..., s. 254-262. Cezar przywrócił w Rzymie również symbole zwycięstw Mariusza nad Teutonami i Cymbrami (Suet., Iul. 11). Być może nie był to jego jedyny sposób nawiązania do zwycięstw Mariusza. Odwołanie się do dawnych rzymskich socii, którzy służyli pod dowództwem Mariusza, mogło być kolejnym tego przykładem Por. M. Deutsch, Caesar and Ambrones... s. $258-259$.

${ }^{63}$ Sall., Cat. 19; Suet., Iul. 9; Cass. Dio XXXVI, 44; E.J. Parrish, Crassus' New Friends..., s. 361; B. Marshall, Crassus..., s. 70-71; M. Piegdoń, Krassus..., s. 102-104. Salustiusz (Cat. 19) podaje, że prawdopodobnie został on zamordowany przez hiszpańskich clientes Pompejusza. 


\section{Bibliografia}

Adcock F.E., Marcus Crassus. Milionnaire, Cambridge 1966.

Albertini A., Romanità di Brescia antica, Brescia 1978.

Badian E., Foreign Clientelae 264-70, Oxford 1958.

Bandelli G., Il governo romano nella Transpadana orientale (90-42 a.c.), „Antichità Altoadriatiche” 1986, 28: Aquileia nella "Venetia et Histria", s. 43-64.

Bishpam E., From Asculum to Actium. The Municipalization Italy from the Social War Augustus, Oxford 2007.

Błaszczyk L.T., Ze studiów nad senatem rzymskim w okresie schyłku Republiki, Łódź 1965.

Bourdin S., Les peoples de l'Italie préromaine. Identités, territoires et relations inter-ethniques en Italie centrale et septentrionale (VIII ${ }^{e} \mathrm{I}^{\text {er }}$ s. av. J.-C.), Rome 2012.

Bradley G., Ancient Umbria. State, Culture, and Identity in Central Italy from the Iron Age to the Augustan Era, Oxford 2000.

Brennan T.C., The Praetorship in the Roman Republic, vol. 2, Oxford 2000.

Bringmann K., Historia republiki rzymskiej, przeł. A. Gierlińska, Poznań 2010.

Broughton T.R.S., The Magistrates of the Roman Republic, vol. 1-2, New York 1951-1952.

Brunt P.A., Italian Manpower 225 B.C.-A.D. 14, Oxford 1971.

Buchi E., Roma e la Venetia orientale dalla guerra sociale alla prima età augustea, w: Studi e ricerche sulla Gallia Cisalpina XI Vigilia di romanizzazione. Altino e il Veneto orientale tra II e I sec. a.c. Atti del Convegno, Venezia, S. Sebastiano, 2-3 dicembre 1997, Roma 1999, s. 303-326.

Cadoux T.J., Marcus Crassus: A Revaluation, „Greece\&Rome” 1956, 3, 2, s. 153-161.

Cary M., Scullard H.H., Dzieje Rzymu, t. 1, przeł. [z ang.] J. Schwakopf, Warszawa 1992.

Cowell F.R., Cicero and the Roman Republic, Victoria 1962.

Dart J., The Social War, 91 to 88 BCE. A History of Italian Insurgency against the Roman Republic, Surrey 2015.

Deniaux E., Patronage, w: A Companion to the Roman Army, ed. P. Erdkamp, Oxford 2007, s. 401-420.

DeSouza P., Piraci w świecie grecko-rzymskim, przeł. J. Lang, Zakrzewo 2008.

Deutsch M.E., Caesar and the Ambrones: (Suetonius Iulius ix. 3), „Classical Philology” 1921, 16, 3, s. $256-259$.

Ewins U., Enfranchisement of Cisalpine Gaul, „Papers of the British School of Rome” 1955, 23, s. 73-98.

Faoro D., "Gentes" e "civitates adtributae". Fenomeni contributivi della romanità cisalpina, w: Simblos. Scritti di storia antica, t. 6, a cura di L. Criscuolo, G. Geraci, A. Bencivenni, Bologna 2015, s. $155-200$.

Gabba E., Dallo stato-città allo stato municipale, w: Storia di Roma, t. 2, Torino 1990, s. 697-714.

Galsterer H., Aspetti della romanizzazione nella Cisalpina, „Antichità Altoadriatiche” 1991, 37: Preistoria e protostoria dell'Alto Adriatico, s. 165-182.

Garnsey P., Scheidel W., Cities, Peasants and Food in Classical Antiquity, Cambridge 1998.

Goldsworthy A., Cezar. Życie giganta, przeł. K. Kuraszkiewicz, Warszawa 2007.

Gruen E., The Last Generation of the Roman Republic, Berkley-Los Angeles-London 1974.

Hardy E.G., Some Problems in Roman History. Ten Essays bearing on the administrative and legislative work of Julius Caesar, Oxford 1924.

Iasbez V.V., Aquileia dalla seconda guerra istrica alletà postsillana, „Antichità Altoadriatiche” 2003, 54: Aquileia dalle origini alla costituzione del ducato longobardo. Storia - Amministrazione Società, s. 119-145.

Iluk J., Kilka uwag o roli M. Liciniusza Krassusa w I triumwiracie, „Zeszyty Naukowe Uniwersytetu Gdańskiego" 1971, sect. H, s. 5-23. 
Kamienik R., Odwrót Spartakusa i fiasko przeprawy na Sycylię, „Annales Universitatis Mariae Curie-Skłodowska" 1960, sect. F, 15, s. 1-20.

Kamienik R., Studia nad topografia powstania Spartakusa, „Annales Universitatis Mariae Curie-Skłodowska" 1973, sect. F, 28, s. 95-124.

Keaveney A., Lukullus, przeł. A. Ziółkowski, Warszawa 1998.

Keaveney A., Sulla: The Last Republican, London 2005.

Kendall S., The struggle for Roman citizenship: Romans, allies, and the wars of 91-77 BCE, [Gorgias Press] 2013.

Kowalski H., Rola polityczna kapłanów w Rzymie w okresie schyłku Republiki, w: W 2500-lecie powstania Republiki Rzymskiej, red. A. Kunisz, Katowice 1995, s. 31-52.

Krawczuk A., Virtutis ergo. Nadania obywatelstwa rzymskiego przez wodzów Republiki, Kraków 1963.

Linderski J., Rzymskie zgromadzenia wyborcze od Sulli do Cezara, Kraków 1966.

Luraschi G., Foedus ius latii civitas - Aspetti costituzionali della romanizzazione in Transpadana, Padova 1979.

Malnati L., Reggio Emilia in età repubblicana, w: Lepidoregio. Testimonianze di età romana a Reggio Emilia, a cura di G. Ambrosetti, R. Macellari, L. Malnati, Reggio Emilia 1996, s. 41—45.

Marsh F.B., A History of the Roman World 146-30 B.C., London 1963.

Marshall B.A., Crassus. A Political Biography, Amsterdam 1976.

Morawiecki L., Monety miejskie Italii w II i I w. p.n.e., w: Miasto w starożytności, red. L. Mrozewicz, K. Balbuza, Poznań 2004, s. 139-166.

Mouritsen H., Italian Unification. A study in Ancient and Modern Historiography, „Bulletin of the Institute of Classical Studies", Supplement 1998, 70.

Mrozek S., Ostatni wódz republiki, Gdańsk 2003.

Parrish E.J., Crassus' New Friends and Pompey Return, „Phoenix” 1973, 27, s. 357-380.

Patterson J.R., Colonization and historiography: the Roman Republic, w: Greek and Roman Colonization. Origins, Ideologies and Interactions, eds. G. Bradley, J.-P. Wilson, Swansea 2006, s. 189-218.

Piegdoń M., Caesar et Transpadani: ludność Galii Cisalpejskiej w polityce Gajusza Juliusza Cezara, „Nowy Filomata” 2004, 8 (4), s. 259-270.

Piegdoń M., Galia Przedalpejska. Studia nad rzymską obecnościa w pótnocnej Italii w III-I w. p.n.e., Kraków 2009.

Piegdoń M., Krassus. Polityk niespełnionych ambicji, [wyd. drugie], Kraków 2014.

Piegdoń M., „Viam fecei...ponteis...poseivei...forum aedisque poplicas heic fecei”. Political Activity of M. Aemilius Lepidus in Northern Italy, w: Within the Circle of Ancient Ideas and Virtues. Studies in Honour of Professor Maria Dzielska, red. K. Twardowska, M. Salamon, S. Sprawski, M. Stachura, M. Turlej, Kraków 2014, s. 197-208.

Piegdoń M., Chłosta mieszkańca Novum Comum a sprawa statusu osady, w: Przemoc w świecie starożytnym. Źródła - struktury - interpretacje, red. D. Słapek, I. Łuć, Lublin 2017, s. 239-268.

Premerstein von A., Legatus, w: Real-Encyclopädie der classischen Altertumswissenschaft, Bd. 23, Stuttgart 1924, szp. 1135-1136.

Purcell N., The City of Rome and the "Plebs Urbana" in the Late Republic, w: The Cambridge Ancient History, vol. 9, eds. J.A. Crook, A. Lintott, E. Rawson, Cambridge 1994, s. 689-728.

Rogosz N., Polityczna rola senatu w Republice Rzymskiej w latach 59-55, Katowice 2004.

Rogosz N., Polityczna rola trybunatu ludowego w Rzymie w latach restauracji sullańskiej (78-70), Katowice 1992.

Rogosz N., Wokół datacji kwestury G. Juliusza Cezara, w: Florilegium. Studia ofiarowane Profesorowi Aleksandrowi Krawczukowi z okazji dziewięćdziesiątej piątej rocznicy urodzin, red. E. Dąbrowa, T. Grabowski, M. Piegdoń, Kraków 2017, s. 221-232. 
Rossignani M.P., Gli Aemilii e l'Italia del Nord, w: Splendida civitas nostra. Studi archeologici in onore di Antonio Frova. Studi e ricerche sulla Gallia Cisalpina, t. 8, Roma 1996, s. 61-75.

Santamato E., Gruppi immigrati e loro gestione a Roma tra II e I sec. a.C., Napoli 2008.

Seager R., The First Catilinarian Conspiracy, „Historia” 1964, 13, s. 338-347.

Seager R., Pompey the Great. A Political Biography, Oxford 2002.

Seager R., The Rise of Pompey, w: The Cambridge Ancient History, vol. 9, eds. J.A. Crook, A. Lintott, E. Rawson, Cambridge 1994, s. 208-228.

Seager R., Sulla, w: The Cambridge Ancient History, vol. 9, eds. J.A. Crook, A. Lintott, E. Rawson, Cambridge 1994, s. 164-207.

Sherwin-White A.N., The Roman Citizenship, Oxford 1973.

Southern P., Pompejusz Wielki, przeł. B. Mierzejewska, Warszawa 2004.

Stockton D., The First Consulship of Pompey, „Historia” 1964, 18, s. 205-218.

Syme R., The Roman Revolution, Oxford 1939.

Tarpin M., Le coloniae lege Pompeia: una storia impossibile?, w: Studi e ricerche sulla Gallia Cisalpina XXVI, Trans Padum... usque ad Alpes. Roma tra il Po e le Alpi: dalla romanizzazione alla romanità. Atti del convegno Venezia 13-15 maggio 2014, a cura di G. Cresci Marone, Roma 2015, s. 200-219.

Taylor L.R., The Voting Districts of the Roman Republic, Roma 1960.

Toynbee A.J., Hannibal's Legacy. The Hannibalic War's Effects on Roman Life, vol. 1-2, London 1965.

Twyman B., Metelli, Pompeius and Prosopography, w: Aufstieg und Niedergang der römischen Welt. Geschichte und Kultur Roms im Spiegel der neueren Forschung, Bd. 1, hrsg. H. Temporini, Berlin-New York 1972, s. 862-873.

Ward A.M., Marcus Crassus and Late Roman Republic, Columbia 1977.

Wiseman T.P., Caesar, Pompey and Rome, 59-50 B.C., w: The Cambridge Ancient History, vol. 9, eds. J.A. Crook, A. Lintott, E. Rawson, Cambridge 1994, s. 368-381.

Wiseman T.P., New Men in the Roman Senate, 139 B.C.-A.D. 14, Oxford 1971.

Wiseman T.P., The Senate and the Populares, 69-60 B.C., w: The Cambridge Ancient History, vol. 9, eds. J.A. Crook, A. Lintott, E. Rawson, Cambridge 1994, s. 326-367.

Zając J., Aquileia. Status administracyjny antycznego miasta (III w. p.n.e.-II w. p.n.e.), „Balcanica Posnaniensia" 1984, 3, s. 207-214.

Zając J., Od Wenetów do Rzymian. Studia epigraficzno-antroponomastyczne (I w. p.n.e.-I w. n.e.), Toruń 1991.

Ziółkowski A., Historia Rzymu, Poznań 2004. 
Maciej Piegdoń

\section{"Transpadanos et Ambranos" in the Political Operations} of G. Julius Caesar in the 60 s of $1^{\text {st }} \mathrm{BCE}$

\section{Summary}

This article discusses the policy of Gaius Iulius Caesar towards the "Transpadani" - the inhabitants of the province "Gallia Cisalpina", who had a Latin status in the 60 s of $1^{\text {st }}$ BCE. Caesar's first recorded political actions were carried out in 67 and 65 BCE. In the 60s Caesar may have begun campaigning for changing the Latin status of the "Transpadani" and for making them legally equal to the rest of the province and Italy. The result of his activities was the building of client relationships that benefited him greatly in the power struggles in fifties and forties of $\mathrm{I}^{\text {st }} \mathrm{BCE}$.

Key words: "causa Transpadanorum", Gaius Iulius Caesar, Northern Italy, "Gallia Cisalpina", "Transpadani" 